\title{
データ入出力端子としてのパイロットポートの活用
}

\author{
鈴木 治* ・竹本孝弘**・添田 忍 ${ }^{* * *}$ ・山下久雄***
}

\section{Practical Use of Pilot Port for Data Output and Input Terminal.}

\author{
Osamu SUZUKI, Takahiro TAKEMOTO, Shinobu SOEDA and Hisao YAMASHITA
}

\begin{abstract}
An ocean going vessel has pilot port that is used by pilot when ship is piloted. The configuration of pilot plug and its ports is provided by IMO. The standard wrote this data terminal might be use on other situation.

This paper describes the standard of pilot port and the pilot port distributor and server made for trial purposes. The authors designed two AIS server and an AIS distributor for temporary use of AIS pilot port. The distributor has one input and two output port, completely works at up to $120 \mathrm{kbps}$. There are two kind of AIS server, one is single process multi threads, two is multi processes single thread. Both servers work on up to 60 clients onboard test. The authors confirmed that pilot port are effective to collect onboard data for crew and researcher and the data can be used ordinary onboard navigational applications such as electrical chart viewer, conning display and our trial utility software. Keywords: AIS, Pliot port, Pilot plug, Data collecting system, Data logger
\end{abstract} キーワード: AIS、パイロットポート、パイロットプラグ、データ収集システム、データロガー

\section{1 はじめに}

AIS (Automatic Identification System, 船舶自 動識別装置) 導入時に、AIS 本体の他、水先人が Pilot plug（以下、パイロットプラグ）を使えるよう にパナマ運河では通達 (1) が出ていることもあり、 国際航海に従事する船舶ではパイロットプラグ用 の接栓である Pilot port ${ }^{(2)}$ (以下、パイロットポー ト）が設置されることが多い。

船上の研究では、様々な船の動静のデータを手軽 に取得したいが、問題は船によって得られるデータ 形式や出力端子が異なっていることである。また、 航海士は日々、表計算ソフトやそのマクロ等でその 船独自の業務を遂行しているが、船の速度や位置と いった基本データをオンラインでその PC やマクロ 等に取り込むのは多くの場合、装備の面で難しいと 聞く。

本研究では、パイロットポートに着目し、規格を 調査し、研究者や航海士が利用するための方法や発
展の可能性について述べる。

\section{2 船上研究と業務に必要なデータ}

どのように船の動静データが研究に利用されてい るか、PC 普及期および GPS 黎明期の平成以降の 日本航海学会論文集 80 号〜123 号で調査した結果 を Table 1 に示す。

搭載機器を実時間で利用又は連続記録した研究は 132 件で、そのうち、練習船以外は 13 件と少ない。 使用されていたデー夕は船位が圧倒的多数で、次い で船首方位である。データの取得方法は、練習船で は特定の船内 LAN や機器を利用しているが、練習 船以外の研究では、記載がないことが多く、船に応 じてそれぞれ異っていると思われる。実例が少ない ことからもわかるように、実際に運航を行う船船で のデータ取得は容易でないことがわかる。このこ とから、船上のデータを利用する研究の発展には、 デー夕取得や保管の利便性だけでなく、データ取得 のための準備の過程を減らす必要がある。

*正会員 鳥羽商船高等専門学校商船学科（广517-8501 三重県鳥羽市池上町 1-1） osuzuki@cargo.toba-cmt.ac.jp

**正会員 東京海洋大学

***非会員 航海訓粿所 
Table 1 Onboard study with navigational instrument on Journal of JIN.

\begin{tabular}{l|l}
\hline Number of Papers (No.80-123) & 1341 \\
Onboard experiment & 132 \\
Without training Ship & 13 \\
\hline
\end{tabular}

筆者らの周辺の航海士からの聞き取り調査では、 航海士の日常業務では、表計算ソフトを多用してい るため、データをオンラインで利用可能なアドオン や、関数化によるデータのユーザ自身のセルでの計 算、表示機能が望まれ、ウェブブラウザによる閱覧 や、CSV(Comma Separated Values) ファイルに よる読込も希望していることがわかった。

\section{3 パイロットプラグとポート}

Table 2 がパイロットプラグとそのポートの端子 形状、信号形式を文献 (2)(3) からまとめたものであ る。9 ピンからなる端子のうち、 5 つのピンが利用 されており、送信、受信共 2 本の信号線とシール ド線で RS422 形式の $38.4 \mathrm{kbps}$ のシリアル通信を 行っている。水先人が差し込むものをプラグ、それ を提供しているのがポートである (2)。パナマ運河 では、この端子と共に近くに AC120V のコンセン トを用意することが規定されている ${ }^{(1)}$ 。電源の確 保および、端子形状の規定されている位置情報等本 船の動静が得られる入出力端子は、他にはない。

\section{1 杼報の入力と出力の機能}

パイロットポートは情報の入力と出力が可能で、 IMO では、航海状態を示す灯火と AIS を接続して

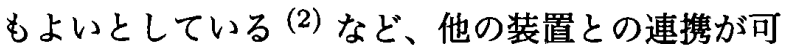
能である。入力可能なセンテンスは AIS の機種に 依存するが、NMEA の VSD センテンス ${ }^{(3)}$ が入力 可能なものを利用した、押しボタン式の航海状態入 力装置を Fig.2 に示す。これは組込マイコン (NEC エレクトロニクス製 78K0S) を使って AIS の航海 状態をサブテレグラフの様に押しボタンで変更し、 その情報をパイロットポート経由で AIS に知らせ るものである ${ }^{(4)}$ 。パイロットポートからの出力は、 NMEA の!AIVDM と!AIVDO センテンスが出カ されている。!AIVDO には、他船情報の!AIVDM と同様に、自船の船首方位、船速、位置の情報が 含まれており (3)、船速に関わらず毎秒出力されて いる。

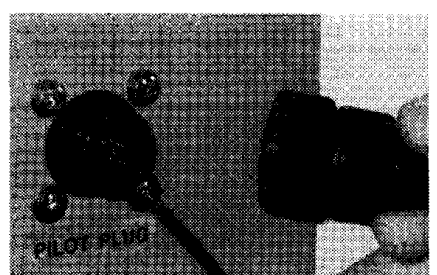

Fig. 1 Pilot port and pilot Plug

Table 2 Pilot port (plug) specification

\begin{tabular}{l|l}
\hline Port(Socket) & AMP 206852-2 \\
Plug & AMP 206485-1 \\
Wired & 2 wires differential \\
Voltage & $0-5 \mathrm{~V}$ \\
Cables & Shieled 4 wires \\
\hline
\end{tabular}

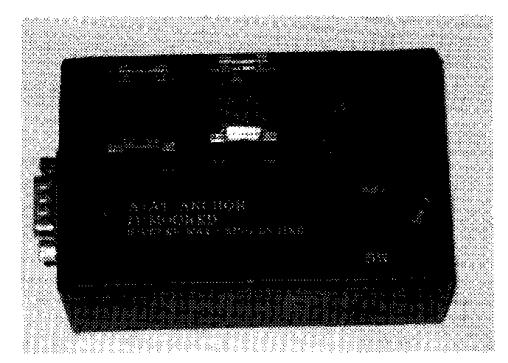

Fig. 2 Button type navigation status selector.

\section{4 パイロットポート分配器の開発}

パイロットポートは端子形状と信号形式が PC で 用いられているものとは異なり、船内ではすぐに対 応できない。また、船橋に 1 つだけ設置されること が多いパイロットポートを研究者や航海士が利用し てしまうと、水先人が利用できなくなってしまう。

恒久的に使用する場合は、パイロットポートを增 設するか、より沉用な端子の新設が望ましいが、研 究目的の一時利用や航海士が乗船中に利用する程 度であれば増設や新設は望めない。本研究ではュー ザ自身が、工事不要で後付けできる汎用なインター フェースを持ったパイロットポート用の分配器を開 発し、水先人以外にもパイロットポートの出力する データを利用可能とする。

\section{1 ハードウエア分四器の櫵成}

パイロットポートの信号を電気的に正しく分配 し異なる信号形式・端子に対応する分配器の基本構 成図を Fig. 3 に、 1 入出力 $\cdot 2$ 出力型の分配器の完 成図を Fig.4に示す。この分配器はパイロットポー ト付近の壁面に取り付けることを想定し、小型薄 
型省電力 $(180 \times 100 \times 47 \mathrm{~mm}, 200 \mathrm{~g}, \mathrm{DC} 9 \mathrm{~V} 0.15 \mathrm{~A})$ になるように設計した。パイロットポートの出力 (TxA と TxB) を RS422 ドライバ IC(MAXIM 社 製 MAX485) に入力して分岐、その後、並列に多 くの USB や LAN、無線 LAN などの変換ユニッ トのある RS232C 形式にするため RS232C ドライ バ IC(Sipex 社製 SP233ACP) を接続した。水先人 の利用を確保するため、パイロットポートと同一形 状のポートも設け、さらに確認用として入力信号と 電源 ONの LED を設けている。ラインテスタ(ラ インアイ社 LE8200) によりドライバ IC の上限の $120 \mathrm{kbps}$ までビットエラーテストを実施し誤動作 がなく、そして鳥羽商船高等専門学校練習船「鳥羽 丸」と航海訓練所練習船「大成丸」の船上で正常に 動作することを確認した。

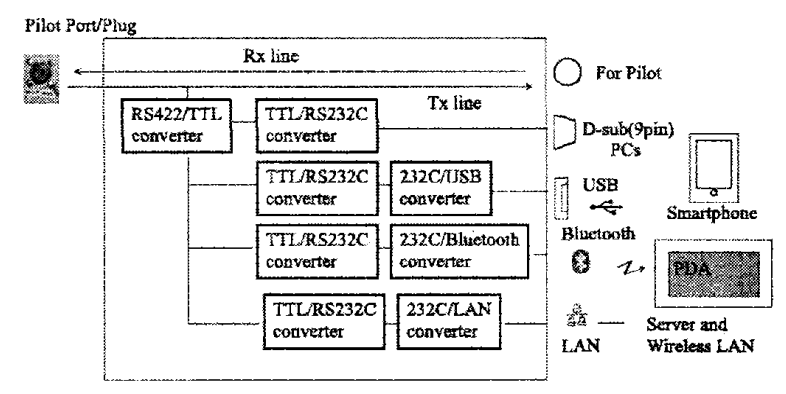

Fig. 3 Diagram of AIS distributor.

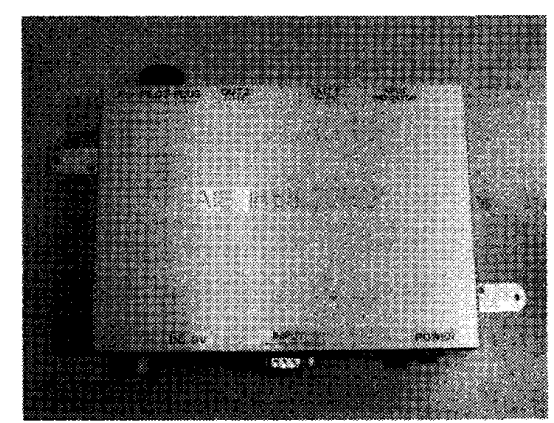

Fig. 4 AIS distributor for pilot port.

\section{2 简便なインターフェースとしての Bluetooth}

これまで機器間の配線不要な方式として無線 LAN が報告 (5)(6) されており利便性は高い。本研 究では、多くの PC や PDA(Personal Digital Assistance、携帯情報端末) に搭載されている、無線 によるシリアル通信として簡便に利用可能な Bluetooth をこの分配器で利用する。Bluetooth は無線 LAN より省電力でかつ無資格で利用できる世界的
な規格であるので国際航海に従事する船舶での利用 に向いている。本研究で利用したのは Class 1(距離 $100 \mathrm{~m}$ 用) の日新テクニカ製 $\mathrm{RS} 232 \mathrm{C}$ 変換型と、PC 内蔵の Class 2(距離 $10 \mathrm{~m}$ 用) の対である。船での 利用の前に、鳥羽商船高等専門学校のグランドの周 囲に遮蔽物がない場所で、2 者間が確実に通信でき る距離を測定したところ、平均で $29.5 \mathrm{~m}$ であった。 練習船「鳥羽丸」(全長 $40 \mathrm{~m})$ の船橋内 $(8 \mathrm{~m} \times 9 \mathrm{~m})^{(7)}$ では船橋右前面の天井に仮設したアンテナから船橋 内のどの場所でも通信が可能であった他、船首の一 部でも通信が可能であり、実用性があることを確認 できた。

\section{3 船内 LAN と多数の端末への対応}

パイロットポートの出力を船内 LAN を含むネッ トワークに配信する場合、デバイスサーバ (8) の利 用は簡便であるが、既存・市販のソフトと機器の多 くがサポートしている TCP 接続の場合、1つのク ライアントしか対応できない。本研究ではネット ワーク上の同時に多数の既存・市販の機器とソフト ウエアへの対応可能な、ソフトウエアによる分配器 「AIS サーバ」を開発した。

Fig.5 は、サーバ機能を組込用のコンピュータ $(24 \times 126 \times 90 \mathrm{~mm}, 150 \mathrm{~g}, \mathrm{DC} 5 \mathrm{~V}, 0.5 \mathrm{~A})$ に実装した ものである。CPU はルネサステクノロジ製の SH$4(266 \mathrm{MHz}, \mathrm{RAM} 64 \mathrm{M})$ で、OS として Linux 2.6 を使用しており、仮想メモリは $64 \mathrm{M}$ バイトである。 プログラムは $128 \mathrm{M}$ のコンパクトフラッシュ上に 展開した。

Fig.6 は、この AIS サーバの性能をプログラムの 種類 (a) と (b) の接続中のクライアント数と、Unix の load average ${ }^{(9)}$ で示している。(a) は、シングル スレッド、マルチプロセス型の、入力したデータを 仮想ファイルとして蓄積しつつ、クライアントから の要求に応じてそのファイルの最後端を読み出す。 (b) はマルチスレッド、シングルプロセス型の、メ モリに最新のデータを蓄積しながら、クライアント の要求に応じてデー夕を提供する。(a) はクライア ントの数に応じて load average とメモリ使用量が 上昇し、負荷が高くなっている。一方、(b) はクラ イアント数に依存せず、一定のメモリを消費するも のの、 load average は上昇せず 0であり、このプロ セスが実行待ちでないことを示している。どちらの プログラムも 60 程度のクライアントに対応できた が、マルチスレッド型の方がより適していることが わかった。 


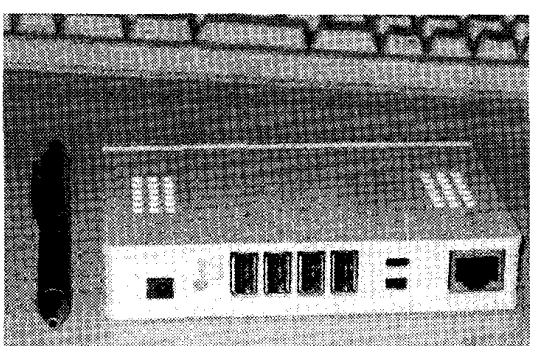

Fig. 5 Software AIS distributor (AIS server on embeded Linux).

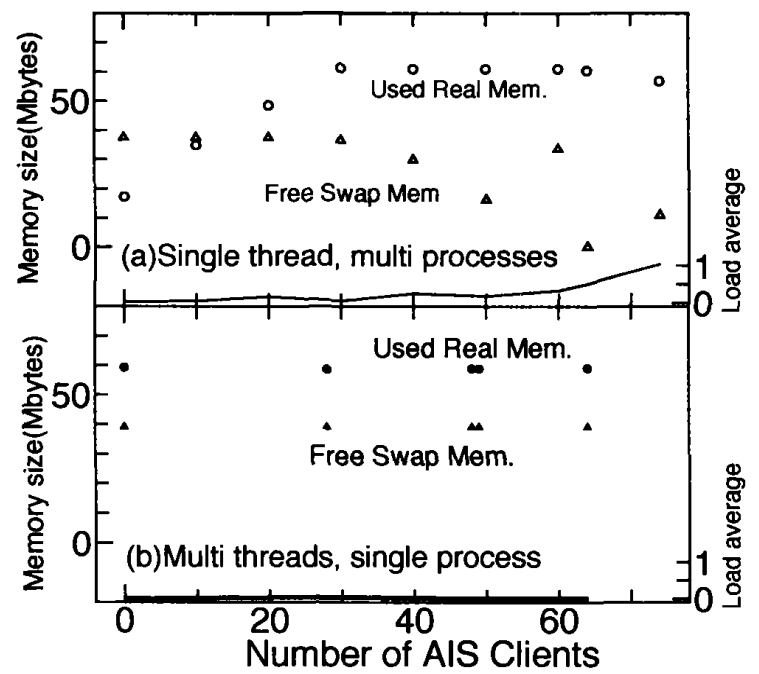

Fig. 6 Load average and memory size each software of AIS server.

\section{5 船内外での利用}

オンラインでデータを得られれば、データベース や表計算ソフトに取り込むことができる(10) など、 そのデータを生かす方法がこれまでの研究論文で報 告されている。そこで、パイロットポートのデータ を具体的に利用する方法を考察する。

\subsection{AIS ロガーと解析}

電池駆動で PC なしに長時間パイロットポートの 出力を記録できる装置「AIS ロガー」を開発した。 Fig.7 は、Logomatic 社製のマイコンボードを利用 したパイロットポートのデータを micro SD カー ド (最大 $2 \mathrm{G})$ に記録する。小型化 $(80 \times 43 \times 25 \mathrm{~mm}$, $100 \mathrm{~g})$ するため、デー夕の記録以外は、電源の ONOFF、記録の有無の表示機能のみとした。充電 とデータの取り込みに USB ケーブルを利用し、 $600 \mathrm{mAh}$ のリチウムイオン電池で、7 時間の連続稼 働が可能である。

Fig.8 は、錨泊の監視を目的に作成されたソフト
ウエア (11) を発展させたもので、練習船「大成丸」 (全長 $125 \mathrm{~m}$ ) の鹿児島港出港の様子を軌跡と船体の 動きで表現している。AIS ロガーで記録されるデー 夕は、パイロットポートから出力されるデー夕その もので、一時間に数 $\mathrm{M}$ バイトであるのでデータロ ガーの microSD カードに十分記録が可能である。 現在、本ソフトウエアは青雲丸、海王丸でも利用中 で、AIS ロガーのデータを使用するには一度、デー 夕変換が必要であるが、自主開発しているので、そ の機能を同ソフトに組込むことも可能である。

\section{2 船内各所ての利用}

AIS サーバを利用すれば、船内外の各所で船橋と 同じデー夕を見ることが可能になる。大成丸の航 海士 10 名に、そのメリット、問題点を記名式で意 識調査を行った。「船橋以外の船内で AIS、ARPA を電子海図上で見られたらどう思うか？」との問い に、過半数が肯定的で、否定的な意見は皆無であっ た。意見として特徴的なものに、“見られるものは 見たい”、“当值前の確認に良い”といった、積極的 な意見が多く得られた。また、「どこで利用したい か？」という問いには、公的な場所の他、“自室で も利用したい”と多くが回答しており、経験が長い 航海士ほど、どこの場所でも確認したいという意見 が得られた。

\section{3 既存のソフトによるモニタリング}

Fig.9 は、パイロットポートからのデータを、陸 上において電子海図表示ソフトで表示したものであ る。熊野灘を航行中の大成丸 (左) は $\mathrm{PC}$ 上のピー シースタジオアルファ社の「アルファマップ」を 使ってオフラインで、伊勢湾を航行中の鳥羽丸 (右) は、スマートフォンである iPhone と Northport 社 の「iNavX」を使ってオンラインで表示した。陸船 間の通信回線か、記録があればその船の行動を市販 の表示ソフトで実時間または必要に応じて表示可能 となった。

\section{6 発展可能な毫例検討}

2 章の調査では、船内 LAN や AIS が装備され データ収集が容易になると、関連した研究が発展す ることがわかった。パイロットポートと前節のロ ガーを使えば、船体挙動の収集がすぐに可能になる ので同種の研究が進むと考える。

例えば、大型船の着栈状態の記録や評価では、AIS の受信より頻繁にデータが得られるので港湾設計の 


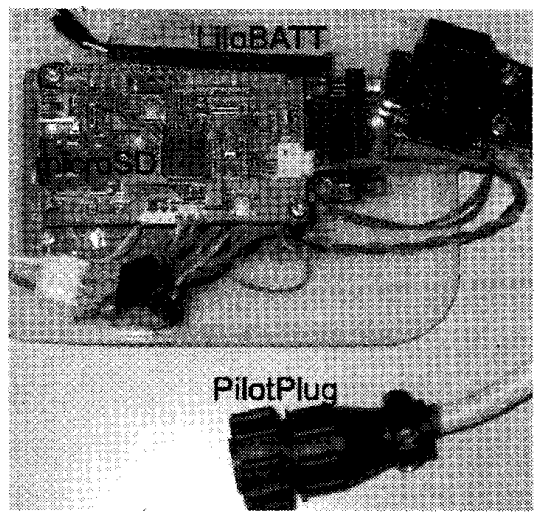

Fig. 7 Simple AIS logger (Pilot plug and LiIo. BATT).

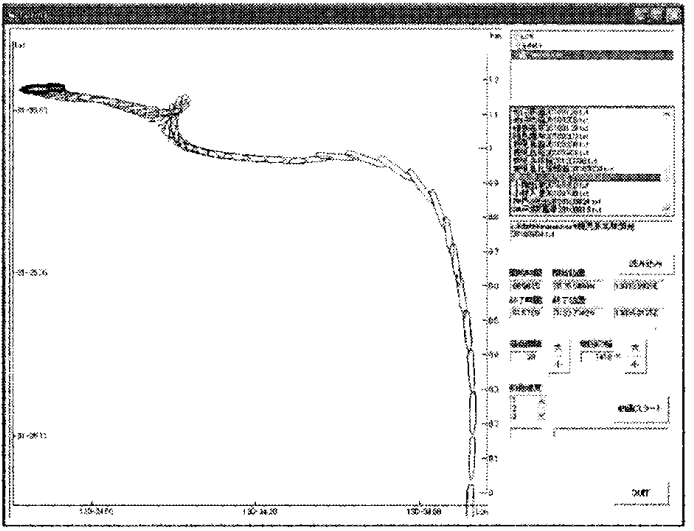

Fig. 8 The view of the software, track and heading when port leaving (T.S. Taisei Maru at Port of Kagosima).

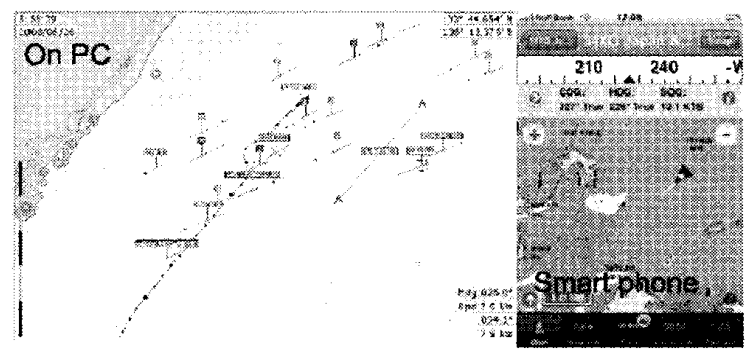

Fig. 9 The view of track and vessels on PC and smart phone (Left: T.S. Taisei Maru, Right: T.S. Toba Maru).

指針に利用できる ${ }^{(12)}$ 。

タグボートの挙動解析 (13) では、実船によるデー 夕収集と模型船との比較が必要とされていた。AIS 搭載のタグボートが増えている現在では、この解析 にパイロットポートからの出力されるデータが利用 できる。

大型船操船用の支援ツール(14)では、操船シミュ
レータ用の表示ッールが提案されているが、本船と 他船の状況がパイロットポートから得られるので操 船シミュレータだけでなく、実船でも効果があるか 確認でき、その結果次第ではさらなる発展が期待で きる。

本研究の成果として、鳥羽丸では、Fig.10に示 す、パイロットポートの隣に D-sub コネクタによ る、NMEA Mixer ${ }^{(15)}$ による NMEA の AIS, GPS, ARPA のそれぞれのセンテンスを混合出力する端 子を増設し “研究船”としての利便性を高めている。

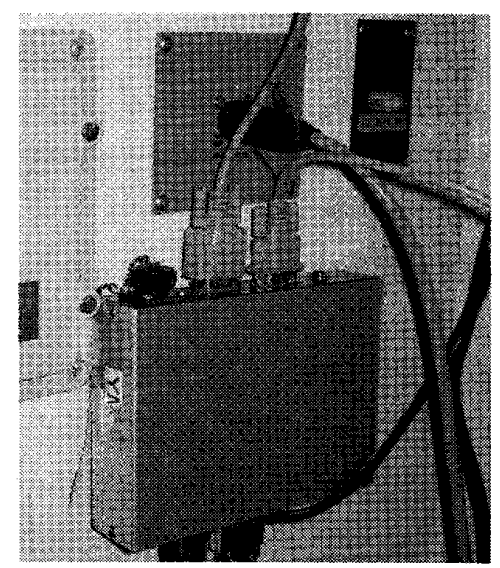

Fig. 10 Pilot port, mentioned AIS distributor and original AIS, APRA and GPS mixing output port, with D-sub 9 pins connector for study use (T.S Toba Maru).

\section{7 まとめ}

本研究では、ユーザが利用可能なデータ入出力端 子としてパイロットポートの規格を調査し、本船で の簡便なる利用方法を検討した結果、工事不要でよ り汎用な D-sub コネクタによる RS232C 形式の端 子を装備したパイロットポート分配器を開発した。 また、AIS のデータをより多くへ配信するためのソ フトウエアによる分配器「AIS サーバ」の開発も合 わせて行い、練習船 2 隻の船上で動作確認を行い、 他の機器に支障を与えず、既存の機器・ソフトウエ アで問題なく動作することを確認した。パイロット ポートは設置場所等の問題が報告 (16) されている が、Bluetooth や無線 LAN を利用できれば、解決 できることも確認できた。

时辞：試作した機器の一部の製作は高橋英次様、 大西貴希様によるものです。AIS 利用に関し、御支 援並びに御意見を賜わった伊勢三河湾水先区水先人 
会の皆様と、AIS 受信機設置やネットワーク利用に 際し、ご協力頂きました関係各位に感謝致します。 なお、本研究の一部は科研費 (20560382) の助成を 受けたものです。

\section{参考文献}

(1) Maritime Operations Director: Reminder on AIS requirements for the Panana Canal, MR'S ADVISORY TO SHIPPING No.A-222003, 2003.7

(2) IMO The Sub-Commitee on Saftey Of Navigation: GUIDELINES FOR THE INSTALLION OF A SHIPBORNE AUTOMATIC IDENTIFICATION SYSTEM (AIS), SN/Circ.227, 2003.1

(3) NMEA 0183 Ver.3.00 : National Marine Electronics Association, p.64, pp.74-76, 2000.7

（4）鈴木治 - 田中友規 - 川瀬悠 - 瀨田広明 - 濱地義 法・鈴木秀司 : 押しボタン式航海状態入力装置の 開発, 日本航海学会学会誌, No.173, pp.65-70, 2010.6

(5) 三輪誠・若林伸和・矢野吉治:無線 LAN による 船内 LAN 構築と船内監視システム, 日本航海 学会論文集, No.114, pp.243-250，2006.3

(6) 村山雅巳・山岸史典:鋼船における無線 $\mathrm{LAN}(\mathrm{Wi}-\mathrm{Fi})$ 機器利用のための基礎調查，日本 航海学会論文集, No.121, pp.95-102，2009.09

(7) 三井造船：鳥羽丸の概要, 船の科学, pp.28-36, 1994.12

（8）例えば、小野泰正：シリアルーイーサーネット 変換器 XPort 使用リポート,トランジスタ技 術, pp.123-126, CQ 出版, 2003.9

(9) Michael Lucas : FreeBSD システム管理とチ ューニング, p.339, p.529, 毎日コミュニケー ションズ, 2004.10

(10) 矢野雄基:航海士のための RDBMS を使った 情報記録・表示システムの開発, 2008 電子情報 通信学会情報システムソサエティ総合体大会特 別号, p.76, 2009.3

(11) 矢吹英雄・山下勝博・斎藤重信 : 実船実験にお ける守錨基準の検討と錨泊状態モニ夕装置の提 案, 日本航海学会論文集, No.108, pp.67-74, 2003.3

(12) International Association of Ports and Harbors:Approach Channels A Guide for De- sign, pp.47-49, Permanet International Association of Navigation Congresses

(13) 定兼廣行・境善行：タグボート推進器後流に よる曳引力減少に関する考察, 日本航海学会論 文集，No.107，pp.115-120，2002.9

（14）白井英夫 - 馬 蓉 -井上欣三 - 広野康平 : 操舵操 船に関する視覚教材の開発とその教育効果, 日 本航海学会論文集, No.108, pp.115-120, 2003.3

（15）鈴木治・田中友規・浪江宏宗・藤井肇: 海上交通 流把握のための陸と船からのデータ収集システ ム, 日本航海学会論文集, No.123, pp.111-117, 2010.9

(16) Colin R. Pratt :AIS - A Pilot's Perspective, pp.181-188, The Journal of Navigation, No.57, 2004.5

\section{付録：部品の詳細と入手}

パイロットプラグは、Fig.11に示す、左からプラ グ (206485-1, 490 円)、内部カバー $(207490-1,283$ 円)、外部カバー (207489-1, 324 円) と、プラグ内 の半田付け用ピンソケット (66569-3, 9 本、1 本 39 円) からなっている。コネクタ内の端子が別売り で、圧着端子用と半田付け用が用意されているのが 特徵である。2010 年 6 月、筆者らはインターネッ ト上の部品店を利用して上記の価格で入手した。

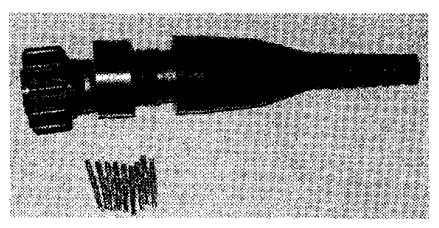

Fig. 11 Parts of pilot plug.

\section{貿疑応答}

広野康平（神戸大学）：

パイロットポートやプラグのコネクタの型が 決定された経緯がわかれば教えて下さい。

鈴木 治 :

資料や文献、インターネットで調べたところ でははっきりとはわかっていません。AMP 社 のコネクタは日常生活では見かけませんが、車 載やネットワーク部門では主流のようですの で、開発者にとってのなじみのコネクタを利用 したのかもしれません。そういった意味では、 
日本の研究者にとってはなじみがないだけかも しれません。また AMP 社は Tyco Electronics 社に合併されたために販売は継続中ですが、こ れがなじみがない理由の一つかもしれません。

田中隆博 (海上保安大学校):

データを取得したい時に限ってパイロットプ ラグが使われているケースがあると思います。 パイロットポートからの出力は IEC 61162-2 の出力そのものなので予備のポートを使用し てD-sub コネクタ, RS232C に変換しておく方 が、パイロットプラグを使うより使い勝手が良 いのではないでしょうか。

\section{鈴木 治 :}

おっしやる通りです。予備のポートが作る ことができる自前の船では、そのようにして おく方が便利なので、練習船「鳥羽丸」では、 ARPA と GPS のデータも混合して出力する D-sub 9pin のコネクタでRS232C 形式で出力 しています。

しかし、内部の配線に触ることができない 場合や、簡便に利用したい場合を考えて、パ イロットポートを使う、使いやすいインター フェースを備えた分配器を開発しました。 